\title{
Micro cogeneration - rich-methane gasifier and micro gas turbine
}

\author{
Danuta Król ${ }^{1, *}$, Stawomir Poskrobko ${ }^{2}$, and Józef Gościk ${ }^{3}$ \\ ${ }^{1}$ Silesian University of Technology, Konarskiego 18, 44-101 Gliwice, Poland \\ ${ }^{2}$ Technical University of Białystok, Wiejska 45A, 15-351 Białystok, Poland \\ ${ }^{3}$ Technical University of Białystok, Wiejska 45C, 15-351 Białystok, Poland
}

\begin{abstract}
The study presents a concept of integration a gasifier system with distributed generation of electricity and heat cogeneration system based on a gas microturbine. The gas generator is supplied by the RDF fuel from waste and biomass fuel Bio-CONOx. In the scale considered, the cogeneration system is designed to produce $30 \mathrm{kWe}$ of electricity and approx. $50 \mathrm{~kW}$ of heat. Important perspective directions of technology development are: (i) the possibility of gas microturbine to cooperate with the gasifier (up to date, in such systems were used, and continue to apply only piston engines), (ii) the production of syngas in the gasifier (for efficient cogeneration) in the composition of which there is a high content of methane $\left(\mathrm{CH}_{4}=18 \%-22 \%\right)$. In the first step of possible commercialization a mathematical model to simulate single shaft gas turbine cogeneration plant has been developed. In conceptual design is application of microturbine as the prime mover of Combined Heat and Power (CHP) system but with especial emphasis on possible use of a low calorific gas attainable from presented in details a gasifier unit. To support the calculations for preliminary design analysis, a computer program is developed in EES software environment.
\end{abstract}

\section{Introduction}

The use of gasifiers in the energy sector is limited by too low efficiency of chemical energy conversion in the fuel, into chemical energy derived from post-processing gas. When the process is carried out in a fixed bed of solid fuel under low pressure conditions (atmospheric), the efficiency of fuel conversion into gas (chemical effectiveness) reaches up to approx. 60$70 \%$. The chemical effectiveness is defined by the ratio of the calorific value of the charge to the calorific value of the resulting syngas [1]. Paper [1] describes the technology of gasification in fluidized compact bed, which has successfully been implemented in the 50s60 s. Later research aimed at improving the chemical efficiency by improving kinetic conditions of the gasification process were carried out using catalysts [2,3]. The increase in the conversion rate was achieved by improving the construction of gasification chambers. Gasification in cyclone chambers [4], with fluidized grate in bladder and circulation bed [5],

\footnotetext{
*Corresponding author: dankrol@wp.pl; danuta.j.krol@polsl.pl
} 
double layer gasification [6], gasification in plasma [7]- all these were implemented. The effect of process improvements has been achieved by reactive additives to fuels, that affect the increase in the content of flammable components in the generator gas, which translates into an increase in the calorific value of the syngas. For example, various types of biomass containing resin pine biomass, biomass or coal with plastics [8] etc. are gasified. The additives to fuels do not play the catalyst role, they are additional fuel- a substrate taking part in the thermal change process. Their participation does not significantly increase the calorific value of the fuel. Their share in the fuel directs the process towards obtaining combustible gases i.e. in particular $\mathrm{CO}$ and $\mathrm{H}_{2}$. The best results, taking into account the technology used, were obtained during gasification in a fluidized bed [9]. Fluid technologies were successfully implemented in Finland, Austria and the USA, where syngas with a calorific value of approx. 6-8 $\mathrm{MJ} / \mathrm{Nm}^{3}[10]$ was obtained.

The paper presents possibilities of generating the syngas in the gasification process of pellets fuel from waste (RDF), with methane forming addition of Bio-CONOx [11]. The resulting gaseous fuel with high calorific value, achieved through significantly increased content of $\mathrm{CH}_{4}$. Such obtained and tested gasifier system can be treated as a very interesting source of fuel which is applicable to supply a gas microturbine and consequently to create a concept of cogeneration plant designed for supply industrial process or residential needs with pressurized, hot water.

\section{Materials and methods}

\subsection{Properties of RDF and Bio-CONOx}

The RDF pellets fuel used in these studies is generated from the combustible fraction of municipal waste. The preparation Bio-CONOX is composed of combustible biomass waste materials. Tables 1 and 2 show RDF and Bio-CONOX preparation fuel properties.

Table 1. Pellets fuel properties of RDF on a dry weight basis and elemental composition of flammable substance expressed on a dry ash-free basis.

\begin{tabular}{|c|c|c|}
\hline Properties & Symbol & Value \\
\hline Moisture content & {$[\%]$} & 5.4 \\
\hline Flammable fraction & {$[\%]$} & 87.1 \\
\hline Nonflammable fraction & {$[\%]$} & 12.9 \\
\hline Lower heating value LHV & {$[\mathrm{kJ} / \mathrm{kg}]$} & 21798 \\
\hline carbon $c^{\text {daf }}$ & {$[\%]$} & 66.7 \\
\hline hydrogen $h^{\text {daf }}$ & {$[\%]$} & 7.5 \\
\hline nitrogen $n^{\text {daf }}$ & {$[\%]$} & 4.1 \\
\hline sulphur $s^{\text {daf }}$ & {$[\%]$} & 1.8 \\
\hline chlorine $c l^{\text {daf }}$ & {$[\%]$} & 0.3 \\
\hline oxygen $o^{\text {daf }}$ & {$[\%]$} & 19.6 \\
\hline
\end{tabular}


Table 2. Physical, chemical, and fuel properties of Bio-CONOx expressed on a dry basis and elemental composition of flammable substance expressed on a dry ash-free basis.

\begin{tabular}{|c|c|c|c|}
\hline Properties & Symbol & Value acc. [16] & Value \\
\hline $\begin{array}{c}\text { Moisture content } \\
\text { Flammable } \\
\text { fraction }\end{array}$ & {$[\%]$} & $<12$ & 7.3 \\
\hline $\begin{array}{c}\text { Nonflammable } \\
\text { fraction }\end{array}$ & {$[\%]$} & $>90$ & 93.2 \\
\hline $\begin{array}{c}\text { Lower heating } \\
\text { value LHV }\end{array}$ & {$[\mathrm{kJ} / \mathrm{kg}]$} & $>17000$ & 6.8 \\
\hline $\begin{array}{c}\text { Higher heating } \\
\text { value HHV }\end{array}$ & {$[\mathrm{kJ} / \mathrm{kg}]$} & $>15500$ & 17745 \\
\hline $\begin{array}{c}\text { Protein content } \\
{[\%]}\end{array}$ & $24-40$ & 31.0 \\
\hline $\begin{array}{c}\text { Plant fats content } \\
{[\%]}\end{array}$ & $2.5-5.0$ & 4.4 \\
\hline carbon $c^{\text {daf }}$ & {$[\%]$} & $49.00-52,00$ & 50.2 \\
\hline hydrogen $h^{\text {daf }}$ & {$[\%]$} & $6.00-8,00$ & 6.3 \\
\hline nitrogen $n^{\text {daf }}$ & {$[\%]$} & $6.00-8.00$ & 5.9 \\
\hline sulphur $S^{\text {daf }}$ & {$[\%]$} & $1.00-1.5$ & 1.2 \\
\hline chlorine $c l^{\text {daf }}$ & {$[\%]$} & $<0.05$ & 0.02 \\
\hline oxygen $o^{\text {daf }}$ & {$[\%]$} & $30.45-38.00$ & 36.38 \\
\hline
\end{tabular}

RDF fuel and mixtures of the fuel with Bio-CONOX 13\%, 23\%, 33\% were applied to the gasification process.

\subsection{Test stand}

Gasification was carried out on a laboratory scale, in the tubular gasifier with fluidized bed (Fig. 1). The gasifying agent was air $(0.64 \mathrm{~g} / \mathrm{s})$ that was that was feed to the bed by a perforated grate from below the gasifier. The diameter of the perforation-hole in the grate $\mathrm{d}=1 \mathrm{~mm}$. During the experiment the air was not heated - the air temperature was $22^{\circ} \mathrm{C}$. The maximum thermal power of the gasifier was $5 \mathrm{~kW}$. The temperature of the process was defined in the range of $380-410^{\circ} \mathrm{C}$, and above the layer of fuel approx. $900^{\circ} \mathrm{C}$. In a fluid bed (in the layer of fuel) - at a temperature of $380-410^{\circ} \mathrm{C}$ - the gasification process occurred autothermally. In the gaseous phase (above the bed), the temperature reached $880-930^{\circ} \mathrm{C}$. An intense evaporation of high-calorific condensable substances, including tar, occurred. It is suggested that these high-calorific compounds were partially burned over the fuel layer in an atmosphere of unreacted oxygen, which resulted in the temperature increase up to the value of $\sim 900^{\circ} \mathrm{C}$. That is evidenced by the lack of high-calorific hydrocarbons $\mathrm{CnHm}$ in the generator gas.

The fuel was fed into the reaction chamber continuously with a feed screw driven by a stepper motor, with a precise speed control, i.e. $0,41 \mathrm{~g} / \mathrm{s}$ fuel flow. The ash was removed in the process exhausting from the gasification chamber by revolving (vacuum and performance) of the exhaust fan rotor. The resultant gas was cooled by a stream air sucked from the environment to a temperature of approx. $180^{\circ} \mathrm{C}$. The gas generator and blowing air 
channel are fitted with electric heating system, which is used to heat the reaction zone, where spontaneous combustion of fuel took place. The stabilization of the process was carried out by regulating the flow of fuel and the gasification air flow.
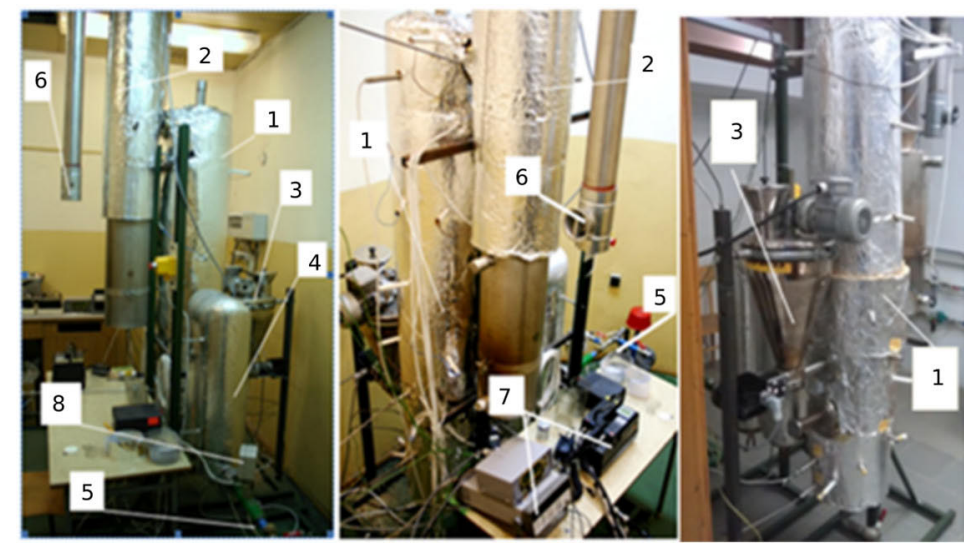

Fig. 1. Laboratory test stand - fluidized bed gasifier, where: 1 - gasifier, 2 - combustion chamber and chimney channel, 3 - fuel tank and dosing system, 4 - air heater, 5 - air flow channel and fan, 6 control chimney draft, 7 - control panel, 8 - measurement of airflow.

\section{Results and discussion}

\subsection{Formatting the text Gasification}

The test results of RDF fuel gasification containing formulation Bio-CONOx are shown in Fig. 2 and 3. Fig. 2 shows the dependence of the of generator gas composition $\mathrm{CH}_{4}, \mathrm{CO}, \mathrm{H}_{2}$, $\mathrm{CO}_{2}$ from the amount of oxygen. Taking into account that the air flow during the gasification process was maintained at a constant level, the demand of the oxygen is significantly reduced, with increasing participation of the additive Bio-CONOx in the fuel (Figure 2). This is expressed in increasing participation of oxygen in the generator gas. These results show, that the addition of Bio-CONOx clearly influences the formation of strongly reducing zone in the reaction environment. Under these conditions the temperature in the bed was maintained in the range of $380-410^{\circ} \mathrm{C}$, the temperature over the bed gradually grew from $880^{\circ} \mathrm{C}$ (gasification without the addition of Bio-CONOx) to $930^{\circ} \mathrm{C}$ (gasification with $33 \%$ addition of Bio-CONOx). Changes in the temperature suggest the increased participation of condensing vapour cracking (including tars), which favoured methane forming processes

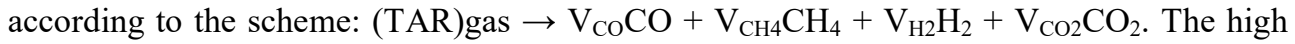
temperature above the bed was assured by the process of partial combustion, mainly highcalorific tars, according to Brydon kinetic model: $\mathrm{CH}_{1,522} \mathrm{O}_{0,0228}+0,867 \mathrm{O}_{2} \rightarrow \mathrm{CO}+$ $0,761 \mathrm{H}_{2} \mathrm{O}$. Gasification of RDF fuel with air made it possible to obtain a synthesis gas, having a composition of combustible gases up to $10,3 \% \mathrm{CH}_{4}, 11,6 \% \mathrm{CO}$ and $7,3 \% \mathrm{H}_{2}$, and calorific value max. at $\sim 6000 \mathrm{~kJ} / \mathrm{Nm}^{3}$.

Gasification kinetics is directed by a complex interdependence of chemical and physical phenomena. The speed of heterogeneous gasification reactions depends both on the speed of chemical reactions, and the speed of diffusion of the gasifying agent into the pores of fuel:

$$
V r=-d n c / d t=f\left(k_{e f}, O,{ }_{m r}, C, w, p, d\right)
$$


where: $k_{e f}$ - effective reaction speed constant; $O$ - specific surface area of the fuel; $m_{r}$ - fuel mass in the reaction space; $C$ - the concentration of the gasification agent in the reaction space; $w$ - the flow rate of the reactants; $p$ - pressure; $d$ - diameter of the fuel grains.
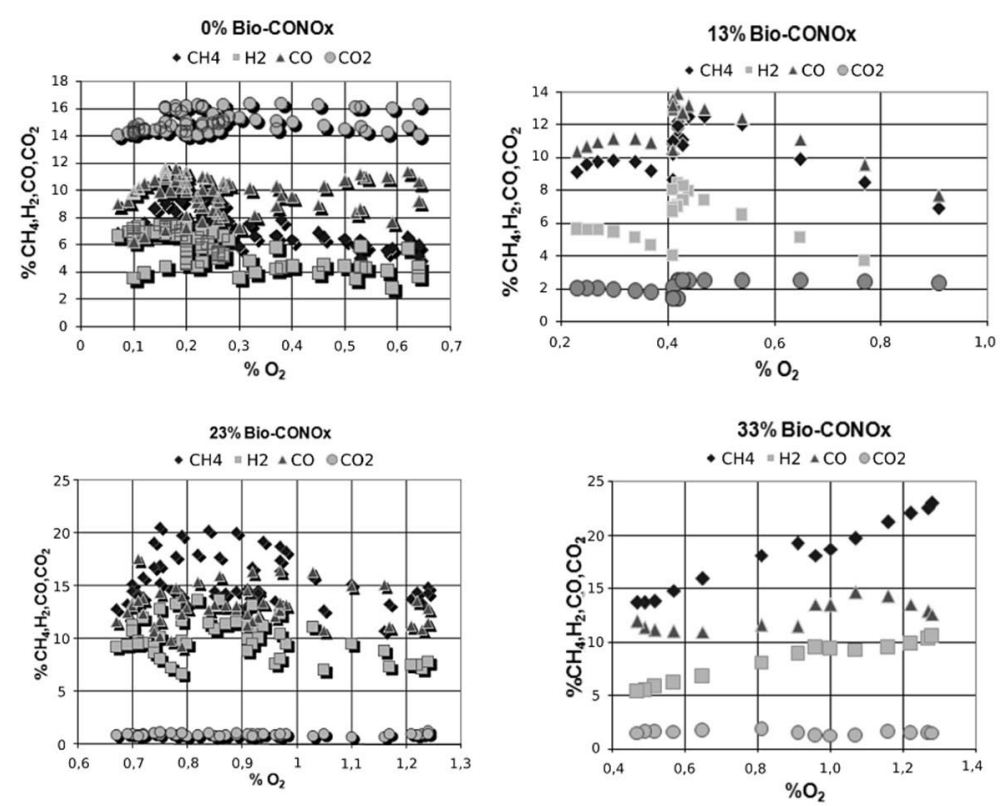

Fig. 2. $\% \mathrm{CH}_{4}, \mathrm{H}_{2}, \mathrm{CO}, \mathrm{CO}_{2}=\mathrm{f}\left(\mathrm{O}_{2}\right)$ for different shares of Bio-CONOx in the fuel.

The results shown in Figure 2 indicate that use of the preparation Bio-CONOx in amounts of 13,23 and $33 \%$ of the fuel mixture, causes expansion of the reducing zone. The result is a continuous increase in the proportion of methane $\mathrm{CH}_{4}$ (even double with the $33 \%$ share of Bio-CONOx in the fuel) and hydrogen $\mathrm{H}_{2}$ in the syngas. Attention is drawn to a significant drop in carbon dioxide content from $16 \%$ (for the gasification of RDF fuel only) to a very low level of $1 \div 2.5 \%$ when Bio-CONOx was added. In addition, the amount of $\mathrm{CO}_{2}$ in the process remains unchanged (Figure 2 - points are arranged parallely to the axis $\mathrm{X}$ ). This reflects the dominant reducing zone in the area of the gasification reaction, favouring the increase of $\mathrm{CH}_{4}$ share. The primary objective of the processes of the second and third generation is, among others, the preparation of higher calorific gas consisting mainly of methane. The obtained results clearly fit in with this trend. They show that in the area of the fuel layer, in favorable temperature conditions $380-410^{\circ} \mathrm{C}$ [15], exothermic methanation reactions occurred. Basic relations oriented towards methanation of synthesis gases are:

$$
\mathrm{CO}+3 \mathrm{H}_{2} \leftrightarrow \mathrm{CH}_{4}+\mathrm{H}_{2} \mathrm{O} \quad \Delta \mathrm{H}=-206 \mathrm{~kJ} / \mathrm{mol}
$$

The water formed during the methanation reaction also reacts with carbon monoxide according to the equation:

$$
\mathrm{CO}+\mathrm{H}_{2} \mathrm{O} \leftrightarrow \mathrm{CO}_{2}+\mathrm{H}_{2} \quad \Delta \mathrm{H}=-41,5 \mathrm{~kJ} / \mathrm{mol}
$$

When in the reaction system the concentration of carbon monoxide decreases, the balance of the reaction (3) moves. This reaction changes direction. It begins to occur from the right side to the left. 
Carbon monoxide which is being formed undergoes the methanation according to equation (2). By adding reaction (2) to reaction (3) - with its course from right to left - we get the sum equation of the carbon dioxide methanation reaction:

$$
\mathrm{CO}_{2}+4 \mathrm{H}_{2} \rightarrow \mathrm{CH}_{4}+2 \mathrm{H}_{2} \mathrm{O} \quad \Delta \mathrm{H}=-164,9 \mathrm{~kJ} / \mathrm{mol}
$$

Hydrogen in the low-temperature thermal conditions of deposit, was created in the radical reactions $\mathrm{H}^{*}+\mathrm{H}^{*} \rightarrow \mathrm{H}_{2}$ and that hydrogen was involved in the methanation reaction of $\mathrm{CO}$ and $\mathrm{CO}_{2}$. Methanation reactions of $\mathrm{CO}$ and $\mathrm{CO}_{2}$ are exothermic reactions taking place with the reduction of volume, so reducing the temperature favours the shift of the equilibrium in the direction to increase methane concentration in the equilibrium gas mixture. The methane forming process is more widely described in[12. Intensification of methanation process for the gasification of fuel with $23 \%$ and $33 \%$ shares of Bio-CONOx, where the highest share of $\mathrm{CH}_{4}$ and calorific value of $\mathrm{LHV}_{\text {syngas }} \sim 10 \mathrm{MJ} / \mathrm{Nm}^{3}$ were recorded. The calorific value of the generator gas was calculated on the basis of the following formula (its source is the instruction manual of the analyzer):

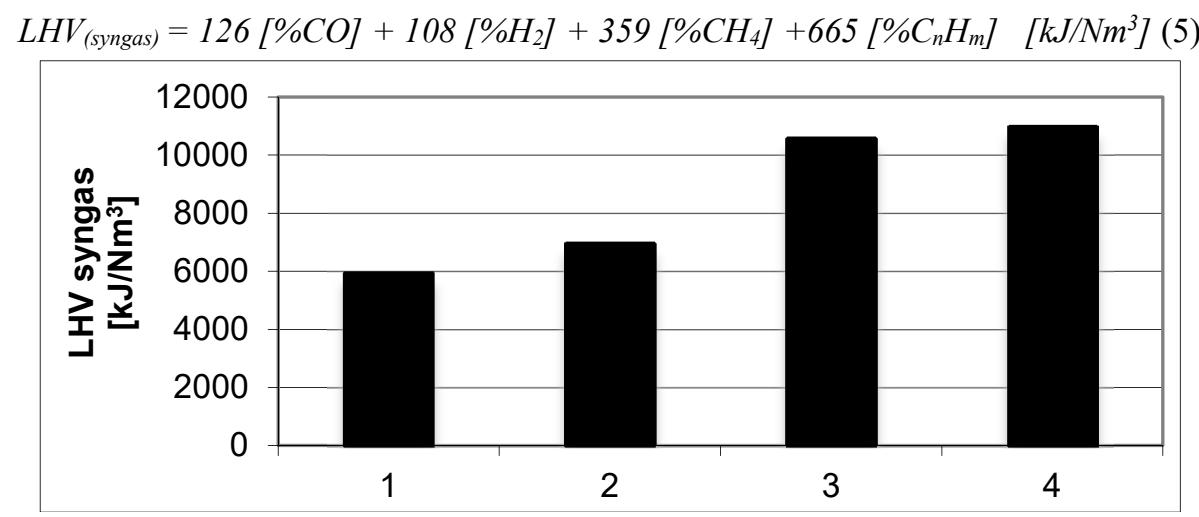

Fig. 3. Calorific value of the synthesis gas depending on the share of Bio-CONOx in the fuel: 1 0\%Bio-CONOx; 2 -13\%Bio-CONOx; 3 - 23\%Bio-CONOx; 4 - 33\%Bio-CONOx

The LHV values of obtained generator gases indicate an upward trend with increasing addition of Bio-CONOx fuel.

\subsection{Modeling of a syngas microturbine based cogeneration plant}

The paper presents a conceptual, small scale cogeneration plant $(30 \mathrm{~kW})$ that combines a gasifier, a single shaft microturbine supplied by syngas and a flue gas heat exchanger (FGHEX). So, it is assumed that worked out units of the plant (gasifier and syngas conditioning parts) can supply a gas microturbine (GM) with so called pure syngas which enable conversion chemical energy to electrical energy and heat without known potential problems. The basic scheme of a cogeneration plant is shown in Fig. 4.

The part of installation responsible for producing syngas were described elsewhere in details. So shortly it is only necessary to mention that for next investigation some idealized Bryton cycle is considered (we assumed as negligible such effects as - to named just a few: air intake and exhaust duct losses and pressure losses in a combustion chamber and in the FGHEX gas side). 


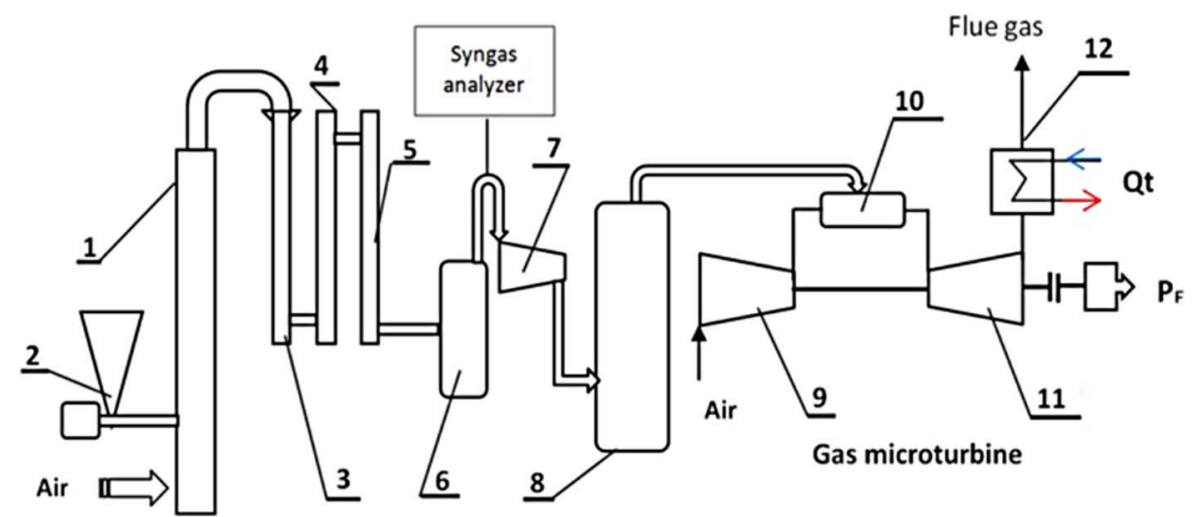

Fig. 4. Simplified scheme of a GM based cogeneration plant: 1-gasifier, 2-feed system, 3,4-scrubbing unit,5-carbon (or ceramic) filter, 6-compensatory syngas container, 7-compressor for syngas, 8container for compressed syngas, 9-GM (air compressor), 10-GM (combustion chamber), 11-GM (expansion turbine), 12-FGHEX, PE-electric power, Qt-heat power.

\subsubsection{Gas microturbine model}

Computational part of the work undertaken concerns mainly on thermodynamic aspects of a microturbine work. The GM consists of four components: compressor, combustion chamber, turbine and generator. At presented paper it is assumed that thermodynamic cycle should be equivalent of classical Brayton cycle (simple, open without regeneration). In the cycle considered atmospheric air (state 1-inlet GM) is continuously drawn into the compressor and then after compression (state 2-outlet GM) is deliver to the combustion chamber. Syngas fuel is used to increase the temperature of compressed air through a combustion process. Hot gases (combustion products) leaving the combustion chamber (state 3) expand in the turbine which produces work to drive the compressor, generator and finally discharges flue gas (state 4 for flue gas also subscript $g 1$ ).

\section{Air compressor model}

Knowing the air inlet temperature $T_{l}$ to compressor, pressure ratio $\pi_{c}$ and isentropic efficiency $\eta_{i(c)}$ for compressor, we can determine the following parameters:

$$
\pi_{c}=p_{2} / p_{1}
$$

where $p_{1}$ and $p_{2}$ are compressor inlet and outlet air pressure respectively;

$$
\eta_{i(c)}=\left(T_{2 s}-T_{1}\right) /\left(T_{2}-T_{1}\right)
$$

where $T_{1}$ and $T_{2}$ are compressor inlet and outlet air temperature respectively, and $T_{2 s}$ compressor isentropic outlet temperature, so the final temperature of the compressor can be obtained from equation

$$
T_{2}=T_{1} \cdot\left(1+\left(\pi_{i(c)}^{p c}-1\right) / \eta_{c}\right) ; \quad p c=\left(k_{c}-1\right) / k_{c}
$$

Assuming that blade cooling is not taken into account, the specific work of the compressor $w_{c}$ and consequently compressor power $N_{C}$ can be calculated by

$$
w_{c}=c_{p(a)} \cdot T_{1} \cdot\left(\pi_{c}^{p_{c}}-1\right) /\left(\eta_{m(c)} \cdot \eta_{i(c)}\right) \rightarrow N_{C}=\dot{m}_{a} \cdot w_{c}
$$

where $c_{p(a)}$ is the specific heat of air and $\eta_{\mathrm{m}(\mathrm{c})}$ is the mechanical efficiency of the compressor. 
From energy balance in the combustion chamber:

$$
\dot{m}_{a} \cdot c_{p(a)} \cdot T_{2}+\dot{m}_{f} \cdot W_{d}+\dot{m}_{f} \cdot c_{p(f)} \cdot T_{f}=\left(\dot{m}_{a}+\dot{m}_{f}\right) \cdot c_{p(g)} \cdot T_{3}
$$

where, $\dot{m}_{f}$ is fuel mass flow rate $(\mathrm{kg} / \mathrm{s}), \dot{m}_{a}$ is air mass flow rate $(\mathrm{kg} / \mathrm{s}), W_{d}$ is low heating value, $T_{3}$ turbine inlet temperature, $T_{f}$ is temperature of fuel, $c_{p(f)}$ is specific heat of fuel and $c_{p(g)}$ specific heat of flue gas. After manipulating (5), the fuel air ratio can be expressed as

$$
F A R=\dot{m}_{f} / \dot{m}_{a}=\left(c_{p(g)} \cdot T_{3}-c_{p(a)} \cdot T_{3} \cdot\left(1 / \pi_{t}^{p g}\right)\right) /\left(W_{d}+c_{p(f)} \cdot T_{f}-c_{p(g)} \cdot T_{3}\right)
$$

Gas turbine model

The exhaust gases temperature from gas turbine is given by

$$
T_{4}=T_{3} \cdot\left(1-\eta_{i(t)} \cdot\left(1-1 / \pi_{t}^{p g}\right)\right) ; \quad p g=\left(k_{g}-1\right) / k_{g}
$$

where $T_{4}$ is also the inlet gases temperature $\left(=T_{g l}\right)$ to FGHEX.

The specific shaft work $w_{t}$ of the turbine and turbine output power are given by

$$
w_{t}=c_{p(g)} \cdot T_{3} \cdot \eta_{i(t)} \cdot\left(1-\left(1 / \pi_{t}^{p g}\right)\right) / \eta_{m(t)} \rightarrow N_{T}=\left(\dot{m}_{a}+\dot{m}_{f}\right) \cdot w_{t}
$$

The MG powers ((9), (12)) allow to express the net output power from the turbine as

$$
N_{G T}=\left(N_{T}-N_{C}\right) \cdot \eta_{g}
$$

If the heat supplied is expressed as

$$
E_{c h}=\dot{m}_{f} \cdot W_{d}
$$

then the gas turbine efficiency $\eta_{t h}$ can be determined by equation

$$
\eta_{t h}=N_{G T} / E_{c h}
$$

\subsubsection{Gas microturbine model Flue gas heat exchanger}

For recover waste heat from gas turbine, exhaust gas flows into FGHEX (it is assumed with $T_{g 1}, T_{g 2}$ inlet and outlet flue gas temperature, respectively). Usually FGHEX represents a single pressure heat recovery steam generator (HRSG) or water-gas heat recuperator.

\subsubsection{Thermodynamic performance}

There are known and commonly used three thermodynamic methodologies for the performance evaluation of cogeneration plant including of course gas fired systems. Two of them are fundamentally energetic providing to calculate fuel utilization efficiency and power to heat ratio efficiency. Third methodology operates on exergetic approach and allow to system evaluation on the base of second low, exergetic efficiency. In the paper for the evaluation overall efficiency we restricted our attention to apply the first approach (named also as Energy Utilization Factor) and defined as

$$
\eta_{o v}=E U F=\frac{N_{T}+Q_{e x}}{E_{c h}} \text { where } Q_{e x}=\left(\dot{m}_{a}+\dot{m}_{f}\right) \cdot \tilde{c}_{p(g)} \cdot\left(T_{g 1}-T_{g 2}\right)
$$

\subsubsection{Results}

All calculations have been performed using EES software. For better reliability of the GM results are compared with the technical data available for commercial microturbine Capstone C30 (in fact data partially are mixed also with those available for model 330). 
Table 3. Microturbine performance data (Capstone Model C30).

\begin{tabular}{|l|c|}
\hline Electrical power $N_{T}[\mathrm{~kW}]$ & 30 \\
\hline Total heat extraction $Q_{e x}[\mathrm{~kW}]$ & 56 \\
\hline Heat added $E_{c h}[\mathrm{~kW}]$ & 115 \\
\hline Flue gas temperature $T_{4}[\mathrm{~K}]$ & $271\left[{ }^{\circ} \mathrm{C}\right] / 544.15[\mathrm{~K}]$ \\
\hline Electrical efficiency $\eta_{e l}[-]$ & 26 \\
\hline Overall efficiency $E U F[\%]$ & 77 \\
\hline Rotational speed $[\mathrm{r} / \mathrm{min}]$ & 96000 \\
\hline Air flow rate at compressor inlet $[\mathrm{kg} / \mathrm{s}]$ & 0.31 \\
\hline
\end{tabular}

Comment: designed for ambient conditions (ISO-standard reference conditions): temperature 288.15 [K], pressure $101.325[\mathrm{kPa}]$, relative humidity $60 \%$.

Table 4. Design parameters for simulation of the model microturbine.

\begin{tabular}{|c|c|}
\hline Compressor & $\pi_{\mathrm{c}}=4,5, \eta_{\mathrm{i}(\mathrm{c})}=0,8, \quad \eta_{\mathrm{m}(\mathrm{c})}=0,95, \mathrm{k}_{\mathrm{a}}=1,4$ \\
\hline Turbine: & $\pi_{i(t)}=4.5, \eta_{i(t)}=0.88, \eta_{m(t}=0.95, k_{g}=1.326$ \\
\hline Combustion chamber: & $\eta_{\mathrm{cc}}=1,0$ \\
\hline Generator: generator efficiency & $\eta_{\mathrm{g}}=1,0$ \\
\hline Mass flow rate of air $[\mathrm{kg} / \mathrm{s}]$ & 0.31 \\
\hline Outlet temperature $[\mathrm{K}]$ & 544.15 \\
\hline Output power $\mathrm{N}_{\mathrm{GT}}[\mathrm{kW}]$ & 30.0 \\
\hline
\end{tabular}

Table 5. Operating parameters of the model GM results of calculation using EES.

\begin{tabular}{|c|c|c|}
\hline \multicolumn{1}{|c|}{ State of cycle } & Pressure $[\mathrm{kPa}]$ & Temperature $[\mathrm{K}]$ \\
\hline 1 - inlet air to the compressor & 101.3 & 288.15 \\
\hline 2 - outlet air from the compressor & 456 & 481.53 \\
\hline 3 - inlet gas to the turbine & 456 & (see Table 6) \\
\hline 4 - gas exhaust from the turbine & 101.3 & 544.15 \\
\hline Compressor input power $\mathrm{N}_{\mathrm{C}}[\mathrm{kW}]$ & \multicolumn{2}{|c|}{63.8} \\
\hline Turbine output power $\mathrm{N}_{\mathrm{T}}[\mathrm{kW}]$ & \multicolumn{3}{|c|}{94.4} \\
\hline Net output power $\mathrm{N}_{\mathrm{GT}}[\mathrm{kW}]$ & \multicolumn{3}{|c|}{30.0} \\
\hline
\end{tabular}

Table 6. Calculated cases for different fuels including design parameters ${ }^{1 /}$.

\begin{tabular}{|l|c|c|c|c|c|}
\hline & Fuel I & Fuel II & Fuel III & Fuel IV & Methane \\
\cline { 1 - 5 } $\begin{array}{l}\text { Temperature of inlet gas to } \\
\text { turbine } T_{3}[\mathrm{~K}]\end{array}$ & 811.2 & 815.3 & 821.1 & 821.3 & 828.3 \\
\hline Mass flow rate of fuel [kg/s] & 0.02216 & 0.0172 & 0.01027 & 0.01007 & \\
\hline Ratio air/fuel AFR [-] & 13.99 & 18.03 & 30.18 & 30.78 & 0.002182 \\
\hline Heat extracted [kW] & 58.229 & 59.112 & 56.996 & 56.961 & 142.1 \\
\hline Heat added [kW] & 107.395 & 107.827 & 108.431 & 108.449 & 55.557 \\
\hline Efficiency $\eta_{\text {th }}[\%]$ & 28.5 & 28.39 & 28.23 & 28.23 & 28.136 \\
\hline Efficiency EUF [\%] & 82.98 & 81.82 & 80.23 & 80.19 & 78.39 \\
\hline
\end{tabular}

Comments: ${ }^{1 /}$ calorific values $W_{d}: 4.847 \mathrm{MJ} / \mathrm{kg}$ - Fuel I, $6.270 \mathrm{MJ} / \mathrm{kg}$ - Fuel II, $10.558 \mathrm{MJ} / \mathrm{kg}$ - Fuel III, $10.769 \mathrm{MJ} / \mathrm{kg}$ - Fuel IV and for pure methane $50 \mathrm{MJ} / \mathrm{kg}$ (all $W_{d}$ based on Lower Heating Values);2' heat extracted rates have been calculated taking reference temperature $\left(T_{g 2}=368,15[\mathrm{~K}] / 95{ }^{\circ} \mathrm{C}\right]-$ the temperature of the exhaust gases exit from the FGHEX). 


\section{Conclusions}

The studies discussed in the paper showed that co-gasifying with air (in compact bed, in the laboratory tubular reactor with a capacity of $5 \mathrm{~kW}$ ) the RDF fuel (from waste) containing the biomass additive Bio-CONOx, a generator gas with a high methane content can be obtained. Bio-CONOx share in the fuel was subsequently: $0 \%, 13 \%, 23 \%, 33 \%$. Temperature distribution in the reaction chamber of the gasifier (in the fuel layer $380-410^{\circ} \mathrm{C}$ and above the fuel layer $880-930^{\circ} \mathrm{C}$ ) allowed to obtain syngas - produced during the gasification of RDF without the addition of Bio-CONOx - with methane content of even approx. $10 \%$. In such conditions, in the layer of fuel, exothermic methanation process took place, i.e. hydrogenation of $\mathrm{CO}$ and $\mathrm{CO}_{2}$, according to the mechanism of Fischer-Tropsch and Sabatier Sanders. Over the fuel at high temperatures, process conditions conducive to cracking tars were created (in line with Brydon kinetic concept). The product of cracking was, among others, methane. The results showed that in the co-gasification process with air of RDF fuel with the addition of Bio-CONOx, the addition significantly affects the methane forming transformations in the gasification process, making the obtained synthesis gas has reach higher calorific value of over $10 \mathrm{MJ} / \mathrm{Nm}^{3}$.

The obtained syngas we used as an interesting and commercially attractive fuel for conceptual design a microturbine combined heat and power a small scale system. At this stage, we firstly presented some important part of the design namely analytically performed sizing of main feeding system. Creation of reliable set of results concerning fuel flow rate (see Table 6) was possible on the base fuel characterization (syngas detailed analysis) and finally combustion concept taken.

In order to develop the cogeneration model and to perform systematic calculations it has been assumed that a commercially available microturbine (Capstone C30) works at nominal, steady state mode of operation corresponding precisely of design point. The very important fixed parameters were: air flow rate at compressor inlet, net output power $\mathrm{N}_{\mathrm{GT}}$ as well as the temperature of gas exhausting the turbine.

Based on the represented findings we can conclude that developed model can be used as a kind of computer tool giving a valuable reference level for necessary modification in concept design and for expediency estimation of improvements in moving a small scale cogeneration systems toward thermodynamic and/or technology perfection.

\section{References}

1. P.D. Lebiediew, A.A. Szczukin. Przemysłowa technika cieplna, WNT Warszawa (1962)

2. W.Zhu, W.Song, W.Lin. Fuel Proc. Techn., 890.(2008).

3. R.Brown, Q.Liu, G.Norto. Biomass and Bioenergy,18, 499,(2008)

4. X.Guo, B.Ciao, S.Liu, Z.Hu, S.Luo, M.He. J of Hydr. En., 34, 1265 (2009)

5. K.Li, R.Zhang, J.Bi. Energy, 352722 (2010).

6. S.Poskrobko S. XII Symp. Wym. Ciepła i Masy, Darłówko, 841 (2007)

7. M. Materazzi, P. Lettieri, R. Taylor, C. Chapman. Waste Manag. 47 256(2016)

8. P.McKendry. Biores Techn. 83, 55 (2002)

9. D.L.Granatstein. Lahti Finland. Natural Resources Canada/CANMET Energy Technology Centre (CETC), IEA BIOENERGY AGREEMENT-TASK 36, (2002).

10. Ch.Hanping, L.Bin, Y.Haiping, Y.Guolai. Z.Shihong. En \& Fuels, 22, 3493,(2008)

11. S.Poskrobko, D.Król, J.Łach. Fuel Proc. Tech.,.101,. 58, (2012)

12. D. Król, S. Poskrobko. Energy 116. 592, (2016). 